\title{
HRAS wt Allele
}

National Cancer Institute

\section{Source}

National Cancer Institute. HRAS wt Allele. NCI Thesaurus. Code C52545.

Human HRAS wild-type allele is located in the vicinity of $11 \mathrm{p} 15.5$ and is approximately $3 \mathrm{~kb}$ in length. This allele, which encodes GTPase HRas protein, is involved in cellular mitogenesis. Mutations of HRAS are implicated in Costello syndrome, bladder cancer and oral squamous cell carcinoma. 